\title{
Geology and Ore Deposits
}

in the Reid Inlet Area

\section{Glacier Bay, Alaska}

By DARWIN L. ROSSMAN

M I N E R A RESOURCES OF ALASKA

GE OLOGICAL SURVEY B U L LE T I N 1058-B

With notes on a

mineralized area near

Lituya Bay

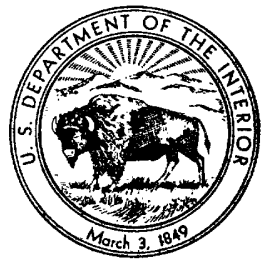




\title{
UNITED STATES DEPARTMENT OF THE INTERIOR
}

\author{
FRED A. SEATON, Secretary
}

\section{GEOLOGICAL SURVEY}

Thomas B. Nolan, Director

The U. S. Geological Survey Library has cataloged this publication as follows :

\section{Rossman, Darwin Lucian, 1915-}

Geology and ore deposits, Reid Inlet area, Glacier Bay, Alaska. With notes on a mineralized area near Lituya Bay. Washington, U. S. Govt. Print. Off., 1958.

iii, 33-59 p. maps (2 fold., 1 col. in pocket) $25 \mathrm{~cm}$. (U. S. Geological Survey. Bulletin 1058-B. Mineral resources of Alaska)

Bibliography : p. 58.

1. Ore-deposits - Alaska - Glacier Bay. 2. Geology - Alaska Glacier Bay. 3. Gold mines and mining-Alaska-Glacier Bay. I. Title: Reid Inlet area, Glacier Bay, Alaska. (Series: U. S. Geological Survey. Bulletin 1058-B. Series: U. S. Geological Survey. Mineral resources of Alaska) 


\section{CONTENTS}

Page

Abstract

Introduction

Geography and accessibility

Acknowledgments.

History

Production

Geology _..

Bedded rocks...

Igneous rocks _...

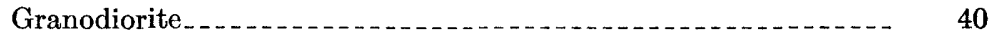

Quartz diorite...... 41

Dike rocks....... 42

Ore deposits

LeRoy mine.......... 45

Incas property

Monarch No. 1.... 48

Monarch No. 2

Rainbow mine

Sentinel vein....... 54

Highland Chief claims. 54

Rambler claims... 55

Other veins

Conclusion

A mineralized area near Lituya Bay

References cited..... 58

Index .

\section{LLUSTRA T I O N S}

Plate 4. Geologic map of the gold-bearing area between Reid Inlet and Lamplugh Glacier, Alaska ..... In pocket

5. Geologic map of workings of the LeRoy mine, Glacier Bay, Alaska In pocket

Figure 5. Index map showing location of the Reid Inlet area._.

6. Map of veins and workings at the Incas property

7. Map of veins and workings at the Monarch No. 1 property _._ 49

8. Map of veins and workings at the Monarch No. 2 property _.. $\quad 51$

9. Map showing location of some hydrothermally altered zones near Lituya Bay, Alaska. 



\title{
MINERAL RESOURCES OF ALASKA
}

\section{GEOLOGY AND ORE DEPOSITS IN THE REID INLET AREA, GLAGIER BAY, ALASKA}

\author{
By Darwin L. Rossman
}

\begin{abstract}
A gold-bearing area of about $7 \frac{1}{2}$ square miles near the head of Glacier Bay between Reid and Lamplugh Glaciers was first discovered by Mr. Joseph Ibach in 1924. The dominant rock type in the area is granodiorite, which is intruded into bedded rocks that may be of Paleozoic age. The bedded rocks consist of conglomerate, limestone, and black graphitic schist. A light-colored quartz diorite younger than the granodiorite crops out south of the mapped area.

Most of the ore deposits are found in fissure-type quartz veins in both the granodiorite and the older bedded rocks. The mineralizing solutions that brought in the gold have altered the country rock for as much as a few tens of feet on each side of the fissures. Locally this altered rock is gold-bearing, but in the places sampled the gold content was found to be too low for mining to be profitable.

Most of the quartz veins are lenticular, both horizontally and vertically, and the gold tends to be concentrated in discrete spots along the veins. These factors cause the ore to be spotty and its location to be unpredictable, and has led to the concept that at many places the ore does not continue below the surface. Geologically, however, there appears to be no reason to believe that gold mineralization is confined to surface outcrop.

The LeRoy and Rainbow properties are the only two within the mapped area that have yielded significant quantities of gold, but the veins on the Highland Chief and probably the Rambler claims appear to be of sufficient size and grade to be potential ore producers.

The LeRoy mine is the largest in the area. The ore body consisted of a fissuretype quartz vein with an average width of 2 to 3 feet and a length of about 60 feet, but in 1954 all the ore in the main vein had been mined out above the main working level. Probably several hundred tons of ore was mined and milled from the Rainbow vein.

The results of an investigation of a mineralized area near Lituya Bay are included in this report. The mineralized material consists of hydrothermally altered rock found in volcanic rocks believed to be of Mesozoic age. The gold content of the observed altered rock is too low for profitable mining, but spots may be discovered in which the gold concentration is sufficiently high to be of economic significance.
\end{abstract}



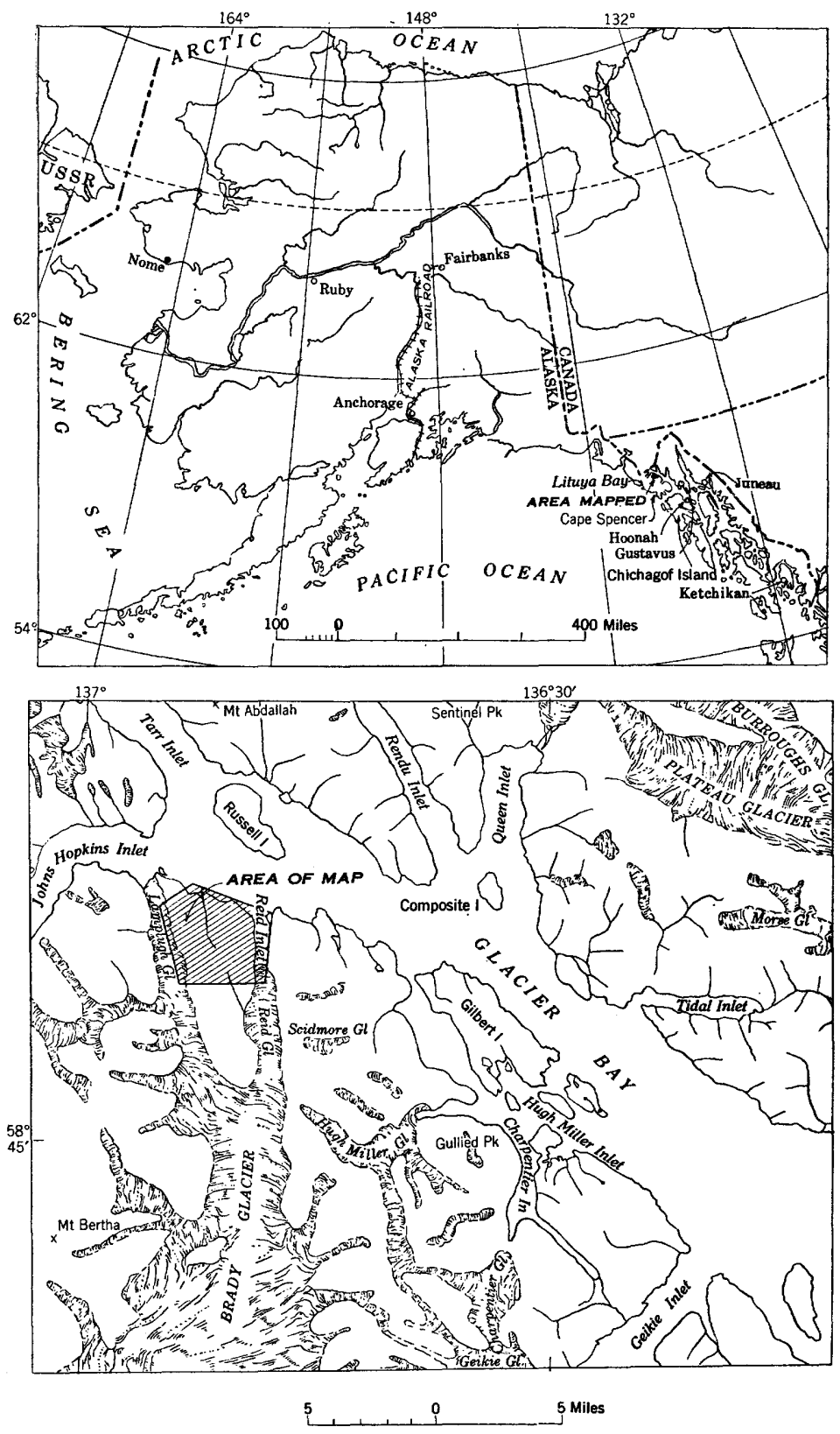

FIGURn 5.-Index map showing location of the Reid Inlet area. 


\section{INTRODUCTION}

The gold-bearing mineralized zone in the area between Reid Inlet and Lamplugh Glacier, known since 1924, has been visited briefly by several geologists. J. C. Reed visited it in 1936 and published a short report (1938). A U. S. Geological Survey party examined the area August 1-18, 1954; the results are summarized in the present report.

The mapped area, about $21 / 2$ miles wide and slightly more than 3 miles long, is near the head of Glacier Bay between Reid and Lamplugh Glaciers, about 150 miles by water from Juneau (fig. 5). Not all of this area has been examined in detail, and certain parts, especially along the south and west sides, have been examined in a single traverse or not at all. A map suitable for plotting the geology was not available, and consequently a base was prepared from aerial photographs by use of multiplex equipment.

\section{GEOGRAPHY AND ACCESSIBIITTY}

The mapped area, which lies entirely within the limits of Glacier Bay National Monument, consists of steep bare mountains bordered on the east by Reid Inlet and Reid Glacier, on the west by Lamplugh Glacier (pl. 4), and on the north by Glacier Bay. The Glacier Bay area as far south as Hugh Miller Inlet is treeless and largely devoid of vegetation. In general, rock exposures are excellent, but the slopes adjacent to Reid Inlet and Glacier Bay are covered with a mantle of glacial debris to an altitude of about 1,000 feet. Many steep-sided gullies have been cut into and through the nearly unconsolidated material, exposing some bedrock even in these covered areas. The bare rock surfaces can be climbed fairly easily, and few spots exist that are totally inaccessible. Although the country can be covered very easily on foot, for the most part, it cannot be traversed by wheeled vehicles.

During some of the time when the claims near Reid Inlet were being prospected, a caterpillar tractor was used. The tractor was brought into the country by way of the Ptarmigan Creek drainage basin while snow still covered the ground. It was possible for the tractor to reach the divide between Ptarmigan Creek and the creek that drains into Reid Inlet at a point near its entrance. From the divide a road was built to the southeast, mainly in unconsolidated material, to a point directly above the Incas prospect on the slope of the mountain west of Reid Inlet, and an aerial tram was built from the end of the road to Reid Inlet. During the summer months while prospecting and mining were in progress, supplies and equipment were brought in, and some ore was removed.

The Rambler group of veins, cropping out about $31 / 2$ miles south of the terminus of Lamplugh Glacier on the west side of the mapped 
area, are difficult to reach. At present the only practical way of building a road would be to extend it along the mountain parallel to Lamplugh Glacier. The mountainside here is solid rock without a soft mantle of overburden, and any road constructed must be blasted out for considerable distances. The surface of Lamplugh Glacier is changing rapidly; however, within the last few years the crevasses have become fewer and more widely spaced, and the surface of the glacier south of the veins has become smooth. If this same trend continues, it may be possible eventually to use the glacier, at least in part, as a means of reaching the veins, though such a route, except in the upper part, was not practical in 1954.

Another deterrent to mining in the area is the abundant snowfall which covers the ground at high altitudes until late summer. For example, some of the veins at the Highland Chief claim at an altitude of about 2,800 feet still were covered by snow when the writer visited the area during the middle of August 1954.

Although no one has spent the winter there, apparently the upper part of Glacier Bay freezes over for extended periods, stopping all navigation. In the past, Glacier Bay and its related bays and fiords have been filled at times by numerous icebergs which would almost prohibit navigation, but this is rapidly becoming less important as the glaciers retreat and become less active. In 1954 the writer experienced little difficulty with the ice. Nevertheless, if large-scale mining operations are to be undertaken, the operators must take into account the fact that impassable barriers of ice will form intermittently in the upper part of Glacier Bay.

There are no large natural harbors entirely sheltered from ice near Reid Inlet, but small boats can find shelter at several places east of Russell Island and at the entrance to Reid Inlet in the small natural bay. However, this bay can be entered only at high tide by boats of small draft. In 1954 little ice beset the area opposite the mouth of Ptarmigan Creek and boats could anchor there for periods of a few days without trouble from ice.

Few climatic data have been recorded for the area. The climate is generally much like that in the rest of the northern section of southeastern Alaska. Precipitation probably amounts to about 85 inches a year. The summer months are the driest, and the fall months from September through December are the wettest. The author has worked in and visited the upper part of Glacier Bay over a period of several years and has found that, although the rainfall may be nearly as great as that farther south on Chichagof Island, there are fewer cloudy or partly cloudy days.

There are no permanently occupied dwellings in the area. A small cabin has been built on the shores of Reid Inlet near its outlet, and 
another on Ptarmigan Creek about half a mile from salt water. A mine mill has been erected about 1,000 feet south of the cabin on Ptarmigan Creek on the northern slopes of Mount Parker. These are the only buildings in the upper part of Glacier Bay. The nearest inhabited dwellings are at Gustavus near the mouth of Glacier Bay. A cabin is maintained by the National Park Service at Bartlett Cove, 6 miles northwest of Gustavus. For the past several years this has been occupied intermittently during the summer months. The nearest settlement where supplies can be purchased is Hoonah about 75 miles by water from Reid Inlet.

There are few land animals in the area. Prospectors have reported seeing several bears, and the author has seen the tracks of wolves south of Reid Inlet. The waters afford a home for large numbers of hair seals, some otters, and water fowl. A few halibut and salmon are caught in the upper part of the bay, and as the ice retreats salmon spawn in more and more of the streams and lakes.

\section{ACKNOWLEDGMENTS}

While the mapping was in progress, Mr. Joseph Ibach of Lemesurier Island kindly spent several days showing the writer those veins and prospects in the Reid Inlet area that were known to him. Mr. and Mrs. Albert Parker also were helpful in making the records and history of the LeRoy mine available. Mr. Phil R. Holdsworth of the Territorial Department of Mines spent several days examining the LeRoy mine with the author and also authorized the use of the base map of the mine which was prepared in the Department's office. This map accompanies the present report and is the one on which the geologic information concerning the LeRoy mine has been plotted (pl. 5). The writer gratefully acknowledges the help and interest shown by these persons.

\section{HISTORY}

Gold-bearing veins were discovered in the Reid Inlet area in 1924 by Mr. Ibach, who first landed near the mouth of the creek, later known as Ptarmigan Creek, and prospected southeastward toward Reid Inlet. At that time Reid Glacier extended nearly to the outlet of Reid Inlet, and no protected harbor existed. He discovered the veins that he staked and named the "Monarch", and the "Incas". A year later, Glacier Bay National Monument was closed to prospecting and mining, and little could be done until 1936 when the monument was again opened. At this time, Mr. Ibach discovered and staked the Rainbow and Sentinel veins near the northern edge of the area. About the same year Mr. Ibach and Mr. Rex Beach discovered and staked the veins on the Highland Chief group of claims. Many other veins were discovered about the same time, including the Galena vein 
near the west shore of Reid Inlet and the Rambler group of veins near the east side of Lamplugh Glacier. Several veins found on the east side of Reid Inlet, including two at an altitude of about 2,000 feet were staked as the Whirlaway and Hopalong claims; and a vein found closer to the shore of Reid Inlet at an altitude of 800 feet was staked as the Sunrise claim. Their location has not been shown on the geologic map.

About the only mining activity before 1937 consisted of sluicing some of the partly decomposed rock from the surface of some of the veins. In 1937 Newmount Mining Co. under the direction of Benjamin Benedict leased the Highland Chief and Rambler claims. They spent several months examining and sampling the veins on these claims as well as on others found within the mapped area. The company gave up its lease after it was decided that the veins were too inaccessible to permit profitable mining. Sometime later, probably before 1941, Mr. Ibach and Mr. Tom Smith started an adit on the Rainbow vein, but, because of lack of proper mining equipment, they soon abandoned the work. They spent the remainder of the season mining the decomposed vein material from the veins on the Galena claim. Similar mining operations were carried out before 1941 on the Whirlaway and Hopalong claims east of Reid Inlet, on the Sentinel vein; on the upper and lower Rainbow veins near the northern edge of the area; and on the Incas veins west of Reid Inlet.

The LeRoy veins, now owned by the Mount Parker Mining Co., were found in 1938 by Mr. Abraham Lincoln Parker and his son, Mr. Leslie F. Parker. The father was a resident and a founder of Gustavus. In his old age, when he had become almost too incapacitated to work, he decided that he wanted to own and operate a gold mine. For several seasons he worked on designing and building a small, two-stamp mill at his home at Gustavus. Upon completion, the mill was dismantled, and he and his son towed it by raft to the upper part of Glacier Bay. They anchored in the small indentation in the shoreline opposite Ptarmigan Creek and decided to start prospecting from this location. Within a few hours, they had discovered the LeRoy vein and had ascertained that it contained a considerable amount of gold. Within a few days they had moved the mill up Ptarmigan Creek to a position below the vein. An aerial tram was built, and mining was started. This is the only instance known to the author in which the mill was actually built before the prospect was discovered.

After the death of Mr. Abraham Lincoln Parker in the winter of 1941, the mine was leased to a group who adopted the name of the LeRoy Mining Co. The six men, namely, Norman Crooks, Raymond 
Crooks, Harry Ellingen, Chris Ellingen, Mike Siler, and Bill Herig, worked the mine during the summer months of 1941, 1942, 1944, and 1945. By 1945 they had mined most of the ore above the main working level in the LeRoy mine and had leased the Rainbow and Incas claims from Mr. Ibach. They milled the ore from the Rainbow claim in the mill on the LeRoy property.

Another mining operation was under way part of the time when the mining was being done by the LeRoy Mining Co. In 1941, the year the LeRoy Mining Co. started operations, four men, August Chop, Joe Repick, Jack Ronning, and Tom Smith, under the name of the Mount Fairweather Mining Co., leased the Monarch claims from Mr. Ibach. That summer an aerial tram was built from the beach on Reid Inlet to a point near the Monarch vein. Ore was mined from the surface of the vein, transported to the beach, and then taken by boat to Lemesurier Island where it was milled and the gold recovered. The operation was not profitable, and the Mount Fairweather Mining Co. gave up its lease at the end of the season.

About 1945, a drift was started on the Monarch No. 1 vein under the supervision of Mr. James Dodson. Development work continued for the next 3 years, and during this time the 200 -foot tunnel was completed on the Monarch No. 1 vein, and another totaling about 150 feet in length was driven on the Monarch No. 2 vein. The tunnel on the Incas property was probably driven before 1951 .

\section{PRODUCTION}

Information on the amount of gold recovered from individual mines is either lacking or incomplete. The amount of gold recovered through the sluicing operations of $\mathrm{Mr}$. Ibach from the surface outcroppings above the weathered veins throughout the area probably amounted to less than 100 ounces. From 1938 to 1950 at least 2,500 tons of highgrade ore, with a recovery of about $\$ 100$ per ton, has been mined and milled from the several mines in the area.

\section{GEOLOGY}

\section{BEDDED ROCKS}

The rocks in the area between Reid Inlet and Lamplugh Glacier are dominantly igneous but include a group of older metamorphosed sedimentary rocks that are entirely surrounded by the granodiorite (pl. 4). Because the sedimentary rocks have little bearing on the ore deposits, it was not deemed worthwhile, for the purpose of this report, to study or describe them at length. They crop out mainly in two sections; one is an elongate band that trends slightly west of north through the central part of the area, and the other is a smaller 
mass that extends from the drainage basin of the east part of Ptarmigan Creek eastward to the headwaters of the largest creek draining into the entrance of Reid Inlet. In both, the strike is parallel to the long direction of the body, and the dip is steep but variable. Mixed sedimentary and igneous rocks also crop out on the mountain between the Highland Chief claims and Lamplugh Glacier on the southern edge of the mapped area. Besides these three fairly distinct zones, which are composed essentially of bedded rocks, a considerable amount of igneous rock in the southern end of the mapped area contains a large amount of almost completely assimilated and recrystallized older rock. In these, the metamorphism has been so complete that the original structure and character of the rock cannot be ascertained in the field.

The bedded rocks consist of a black graphitic rock that is now largely schist, metamorphosed limestone, and conglomerate, listed in the order of decreasing abundance. As far as could be observed, the bedded rocks appeared to be as favorable a host for the ore bodies as the granodiorite. The black graphitic schist, on the other hand, does not appear to be a favorable host rock, for the veins that enter it pinch out within a few tens of feet.

The age of these sedimentary rocks is not known. No fossils were found, and all correlations must be made on the basis of lithologic similarity to rocks of known age. The rocks do not resemble the Mesozoic sequence found farther south on Chichagof Island or in the area between Cape Spencer and Lituya Bay. Yet, they bear a certain resemblance to bedded rocks that crop out in the eastern part of the Glacier Bay area which are believed to be of Paleozoic age. Based on the lithologic similarity of the sedimentary rocks found in the area between Lamplugh and Reid Glaciers, and those on the eastern part of the Glacier Bay area, it is tentatively suggested that the bedded rocks in the mapped area may have been deposited during the middle or late Paleozoic era.

\section{IGNEOUS ROCKS}

\section{GRANODIORITE}

The igneous rocks are largely of granodioritic composition and probably belong to the group of igneous rocks that makes up the Coast Ranges batholith which is believed to have formed during Cretaceous time (Buddington and Chapin, 1929, p. 173-253). The granodiorite in the Reid Inlet area is apparently of at least two slightly different ages, as can be seen by the crosscutting relation shown by one group to the other. The younger of the two appears to be slightly lighter colored than the older. The two rocks have so nearly the same com- 
position and texture, however, that on close inspection they are rather difficult to separate in the field, and it is only when viewed from some distance that the two can best be seen as separate and distinct units. Both are fairly light colored, medium- to coarse-textured igneous rocks containing abundant plagioclase, orthoclase, quartz, and subordinate hornblende and biotite. The rocks have been metamorphosed, and individual grains show preferred orientation.

The metamorphism has been relatively low grade and has resulted mainly in the formation of chlorite minerals at the expense of the hornblende, and in saussuritization and other types of alteration of the feldspar. In most of the thin sections examined, there appears: to have been a later introduction of quartz. The effect of metamorphism in the hand specimen is shown by the dark-colored minerals which no longer exhibit sharp boundaries against other grains but rather grade through an appreciable zone into other minerals. This gives the rock a somewhat lusterless appearance and makes megascopic identification of the dark minerals rather difficult.

Near the southern edge of the mapped area near Reid Glacier, the granodioritic rock has assimilated large amounts of older rock. The recrystallized material is darker colored and contains more ferromagnesian minerals than does the granodiorite. This type of assimilation is common in the igneous rocks in the Glacier Bay area.

No direct evidence was found concerning the age of the granodioritic rocks in the mapped area. Geographically the granodiorite lies in the zone of igneous rocks that intruded the earth's crust in a southeastward-trending belt extending to Chichagof and Baranof Islands. The igneous rocks may have been intruded during the formation of the Coast Ranges batholith in early Cretaceous time. Probably the granodiorite in the area between Reid Inlet and Lamplugh Glacier was formed during this period of igneous activity. The granodiorite is, however, more silicic than most of the rocks belonging to the Coast Ranges batholith, and conceivably it is of a different age and genetically unrelated to the Coast Ranges batholith.

\section{QUARTZ DIORITE}

Another type of igneous rock, which is lighter colored and has a more even texture than the granodiorite, crops out south of the mapped area. This rock, quartz diorite, is neither appreciably metamorphosed nor highly foliated. In outcrop and in the hand specimen, the rock has a fresher appearance than the granodiorite. Because it is essentially unmetamorphosed, and because dikes that are similar to it cut the granodiorite, the quartz diorite is believed to be younger. 
This younger quartz dioritic rock may be correlative with some of the younger igneous, quartz dioritic intrusions on the west coast of Chichagof Island and in the southern end of the Fairweather Range. Those on Chichagof Island are known to cut sedimentary rocks of Mesozoic age and are, therefore, younger. Those in the Fairweather Range cut similar rocks and are believed to be of the same age as those found farther south on Chichagof Island.

\section{DIKE ROCKS}

The rocks in the Glacier Bay area have been cut over large areas by a large number of subparallel dark-green mafic dikes. In areas as much as several square miles in size, these dikes make up at least 30 percent of the total rock by volume. Dikes of the same type are intruded in the area between Reid Inlet and Lamplugh Glacier. Here, as elsewhere in the Glacier Bay area, most of these dikes trend approximately east and are generally nearly vertical. Most of the dikes predate the period of gold mineralization, because they, as well as the country rock, have been altered by the gold-bearing solutions. As far as is known, these dikes are unrelated to those solutions that caused the gold deposits to form. Yet they have influenced the deposition of the ore in at least one place. At the face of the tunnel in the LeRoy mine, one of these dikes cuts diagonally across the fracture that contains the LeRoy vein. The dike appears to have served as a barrier or dam to the ore-bearing solutions and apparently was the cause for the increased width and tenor of the ore in the area adjacent to the dike.

An examination under the microscope shows the dike rocks to be medium grained and to have a diabasic texture. Alteration consists of moderate replacement of the original pyroxene by both a green amphibole and green biotite. Later all three minerals, and probably plagioclase as well, were slightly altered and replaced by chlorite. The pyroxene is augite, which, because of its pinkish color in thin section, is believed to be somewhat titaniferous.

Other similar mafic dikes from the Glacier Bay area contain olivine, and this is probably true also for some dikes between Reid Inlet and Lamplugh Glacier, although none was found in specimens of mafic dikes collected there. The plagioclase has a mean refraction index of 1.57 and is labradorite-bytownite $\left(\mathrm{An}_{70}+\right)$. Plagioclases of two ages are present, but no large difference was found in their indices of refraction and probably both have nearly the same composition. The older occurs as phenocrysts that have been altered very intensely, but the younger consists of clear sharply twinned lathlike crystals of plagioclase that penetrate augite. 
In a few places within the mapped area, the granitic rocks are cut by a light-colored aplitic type of dike rock. Typically, these dikes are irregular in width and rather discontinuous. They both cut and are cut by the dark-colored dikes, and apparently both are of about the same age. The aplite dikes have been metamorphosed somewhat, probably at the same time the granodiorite was metamorphosed. Although fine-grained and texturally somewhat different from the granodioritic rocks, they have almost the same color in outcrop and are rather difficult to distinguish from the granodiorite unless seen on well-exposed fresh surfaces. For this reason they are often undetected. They appear to have little, if any, relationship to the ore bodies or to the ore mineralization. They are altered in the same manner as the country rock adjacent to the ore-bearing veins and thus are undoubtedly older than the period of mineralization.

East of Reid Inlet a few dikes of quartz dioritic composition and granitic texture appear fresh and unmetamorphosed. Because they are unmetamorphosed, they are believed to be younger than the period of metamorphism and perhaps are related to the younger quartz dioritic rock found south and west of the area. None of these dikes were found adjacent to the gold-bearing veins and associated altered zones, and their relation to the gold mineralization is not known. Yet, the dikes are mineralized somewhat, and one specimen contained abundant pyrite and some arsenopyrite. It is reported that other parts of this same dike contain molybdenite, but none was found in the parts of the dike examined.

\section{ORE DEPOSITS}

The gold-bearing veins found in the area were introduced along preexisting fractures in the granodiorite and metasedimentary rocks. Adjacent to these fractures, the wall rock is highly altered. The iron in the altered rock is oxidized easily, and weathering has stained the rock to a rust-red color. On each side of the vein, the visible effects of alteration extend in places 10 to 15 feet. Most of the altered zones contain some gold, but relatively few contain enough to make exploitation profitable. Although the gold is generally found with quartz, at some places appreciable amounts are unassociated with quartz. There is no fundamental genetic difference between the zones with low concentrations of gold and those with concentrations of gold sufficiently high to be classed as ore.

Because the plotted distribution of the altered zones tends to bring out those areas within which the gold-bearing mineralization has been most intense, all known altered zones have been shown on plate 4 . A knowledge of the distribution of these zones should be of value to the 
prospector or geologist working in the area. Many more veins and altered zones occur in the mapped area than have been shown on the map. One area that may contain a large number of these zones is on the mountain slopes above the southwest headwall of Ptarmigan Glacier. Another area know to contain several quartz veins lies on the ridge south of Mount Parker. Many quartz veins crop out on the east side of the mountain facing Reid Inlet, about 3,000 feet northeast of the Highland Chief vein; these have not been shown on plate 4 .

Gold mineralization decreases to the southeast, but a few goldbearing quartz veins occur as far as the southeastern end of Gilbert Island (fig. 5). According to Mr. Ibach, the quartz veins crop out on the mountain facing Lamplugh Glacier near its confluence with Brady Glacier northeast of Mount Bertha. This area is difficult to reach and is virtually unprospected. Mr. Ibach was there for a short time only and reports that he found considerable quartz, both as float on the glacier and in place on the flank of the mountain. He reported one vein to be as much as 50 feet thick. No gold was found in these veins, although one showed some green copper staining. Other than this, the mineralization does not appear to have extended as far west as the west side of Lamplugh Glacier, nor north much beyond the edge of the mapped area, for traces of gold have been reported in only one or two localities in the area north of Johns Hopkins Inlet and in the Tarr Inlet area. Zones of alteration, mostly barren, occur along fractures in the country rock in other parts of the Glacier Bay area north of Hugh Miller Inlet. About the only difference visible in the field between altered zones that do or do not contain gold is that those containing gold also generally contain some quartz, although quartz is not an infallible indicator of gold.

Galena seems to be a good indicator of high gold content, and in many hand specimens specks of gold may be seen either in or adjacent to crystals of galena. In some specimens, the galena has weathered out, leaving a reddish residue in the crystal cavity. The residue in many of these cavities contains small flakes of free gold.

The veins in the mapped area follow several different trends. Those in the area between the Incas and the Monarch veins trend north to northwest in one set and northeast to east in another set. The northto northwest-trending set apparently continues both farther northwest and north into the area between the Rainbow vein and Ptarmigan Creek. The veins on the Highland Chief claims also strike north to northwest. Most of the veins in the area between the Rainbow vein and the entrance to Reid Inlet strike northeast as do most of the veins found in the vicinity of the Rambler vein. The Rambler vein itself, however, has strikes nearly due east. Dips of all the veins in the area 
are steep, the lower limit being about 50 degrees, but there is no consistency in the direction of dip even among veins in the same area or in some places even along a single vein.

\section{LEROY MINE}

The LeRoy mine is on the side of Mount Parker at an altitude of 950 feet (pl. 4). The mine is about 4,000 feet from the beach of Glacier Bay in an air line, or about 1 mile by road and trail. A road has been built up a dry stream channel to Ptarmigan Creek where a cabin and the original mill were built. The newer mill, now partly dismantled, is on the lower slopes of Mount Parker directly below the LeRoy mine at an altitude of about 500 feet. An aerial tram connects the mill to the mine.

The country rock in the immediate vicinity of the LeRoy mine consists of crystalline rock and black graphitic schist. The crystalline rock in part may be of igneous origin; but most of the other rocks. in the same vicinity are undoubtedly recrystallized sedimentary rock, and probably those rocks at the LeRoy mine are of this origin. The veins at the LeRoy mine consist of a northeastward-trending network, which dips $50^{\circ}$ to $80^{\circ}$ to the northwest (pl. 5). The network is fairly well developed, and 15 veins or more crop out in the immediate vicinity of the mine. Although some appear to contain a considerable amount of gold, most are too small to be minable.

The original adit was driven at an altitude of approximately 987 feet along the main LeRoy vein. This level has been mined out completely and was not entered. At the surface the vein is small and makes a relatively poor showing, but underground it increases markedly in width. Another level, almost directly below the first, at an altitude of 950 feet, was driven to mine the ore along the vein. All the ore above this level has been mined out, but quartz still exists in the tunnel along a distance of approximately 60 feet. At one place in the floor of the tunnel the vein is 36 inches thick, but it has an average thickness of about 22 inches over a length of 45 feet.

A third adit was driven about 220 feet northwest of the main working level at the altitude of 950 feet to intersect some of the veins found in that area. Although some ore has been mined in this tunnel, most of the veins here are thinner than those found in the LeRoy mine and are apparently of lower grade.

Another vein, which strikes parallel to the LeRoy vein, crops out about 25 feet to the southeast of the upper adit. This vein has been explored in a short open cut. Samples taken from it have a high gold content. The vein strikes about N. $35^{\circ} \mathrm{E}$. and dips $75^{\circ}$ to $80^{\circ} \mathrm{NW}$., 
and the same mafic dike that cuts across the LeRoy vein strikes about N. $65^{\circ}$ E. and dips about $75^{\circ} \mathrm{NW}$. The dike appears to be older than the quartz vein and has acted as a barrier to the solutions that deposited the quartz and other minerals. If this interpretation is correct, the ore may not continue on the south side of the dike.

All known ore above the main working level has been mined out on the LeRoy vein. Although fairly strong, the vein appears to become somewhat smaller downward in both lateral extent and thickness, and, therefore, extensive future work should be done with caution.

The area south of the dike is covered on the surface, and the positions of veins for several hundred feet south of the dike are completely unknown. Perhaps the vein is present on the south side of the mafic dike but, owing to the fact that the dike appears to have acted as a dam for ore-bearing solutions, it is not likely that the same ore vein continues south of the dike.

Parallel to the LeRoy vein about 22 feet to the southeast lies a group of small veins that, where exposed, are not large enough to mine. They do, however, trend toward the same mafic dike that apparently acted as a barrier to the ore-bearing solutions here as it did along the LeRoy vein. Where exposed at the surface at the discovery, the LeRoy vein is not very wide, and only by drifting along the vein toward the dike could the full extent of the ore body be realized. Inasmuch as the small parallel veins are reasonably close to the LeRoy vein, it would not be difficult or expensive to explore for another ore body.

Most of the other veins found in the immediate area of the LeRoy mine are small. Probably they are too small to be mined economically, although some contain fairly high concentrations of gold. A fairly strong vein that is exposed in the face of the western adit might be explored profitably.

\section{INCAS PROPERTY}

The Incas vein, which was one of the first discovered, was staked by Mr. Joseph Ibach in 1924. The vein lies in a fracture zone in the granodiorite on the mountainside facing Reid Inlet at an altitude of approximately 1,000 feet (pl. 4 and fig. 6). A blacksmith's shop and the foundation of one cabin still remained on the property in 1954 . Near the cabin, a short adit was driven into the mountainside for use as a storage depot during the winter months. Ore was removed from the surface workings of the Incas vein by means of an aerial tram.

The Incas vein trends north or northwest and is exposed intermittently through a thin mantle of glacial debris. For the entire exposed length, nearly 2,000 feet, the country rock has been altered adjacent to the fractured zone. The quartz along this altered zone 
EXPLANATION

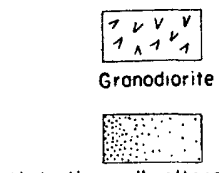

Hydrothermolly altered rock, in part gold bearing

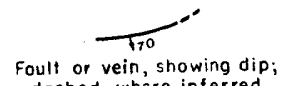
doshed where inferred

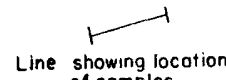
of somples
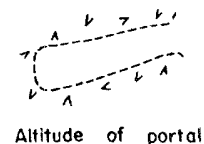
approximately 1000 feet
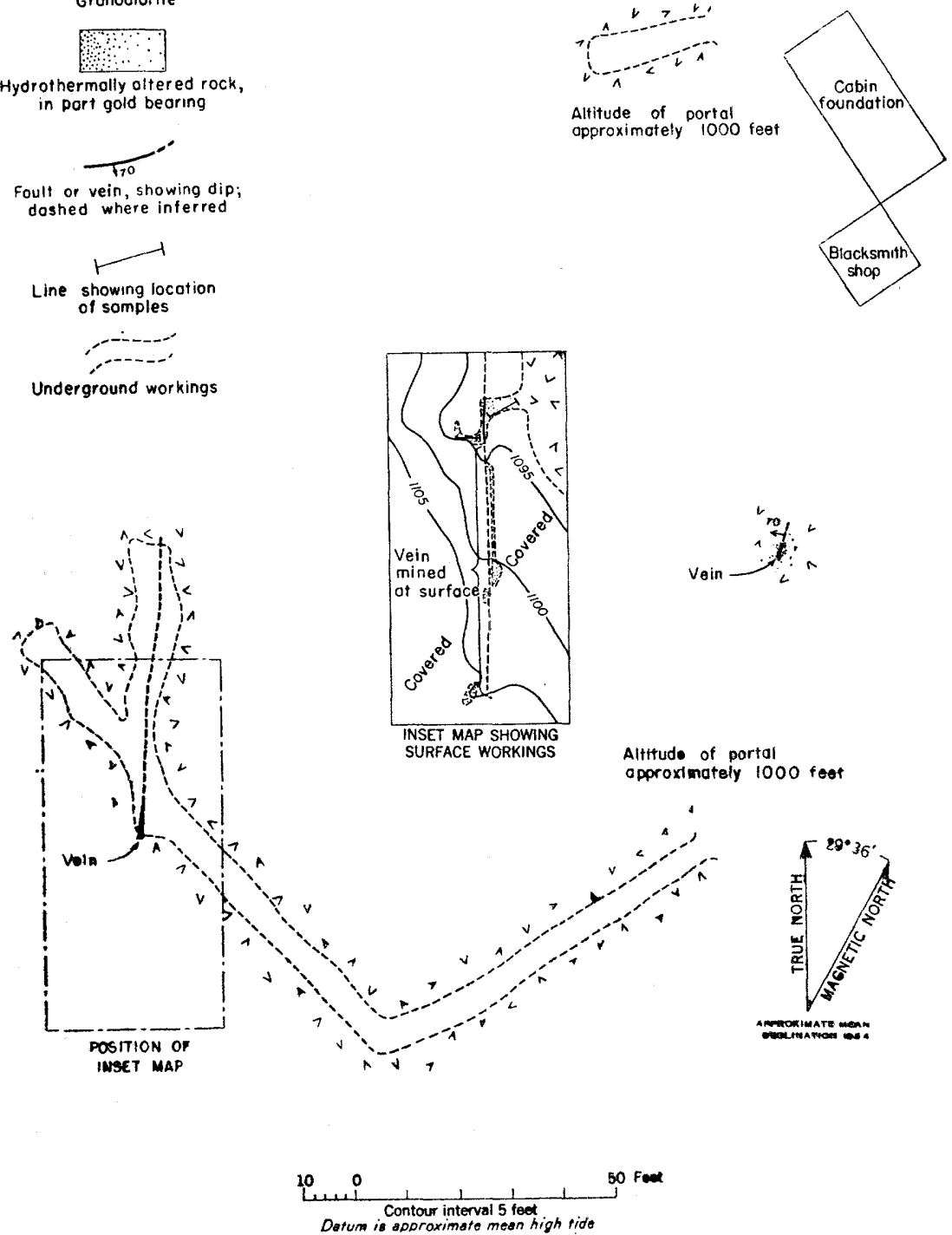

FIGUR= 6.-Map of velns and workings at the Incas property.

is not continuous, however, but apparently consists of a series of lenticular bodies. All the quartz bodies that were found contain some gold.

The main workings are on a vein which was exposed originally on the surface for a distance of approximately 55 feet. The weathered 
part, which extended for several feet below the surface, has been mined. The trench dug during this mining has caved, and the quartz vein, except for several feet on the north end, was covered in 1954.

The tunnel driven to intersect the Incas vein at depth was started at a point approximately 110 feet to the east and about 100 feet lower than that of the surface outcrop of the vein. From the portal, the tunnel was driven at a bearing of S. $60^{\circ} \mathrm{W}$. for a distance of 75 feet and was then turned to the northwest and driven 65 feet to a point where it intersected the fault zone below the northern end of the ore vein on the surface. The tunnel was extended to the north along the fault zone but not to the south under that portion which is known to contain the ore body on the surface. The portal of the main tunnel is somewhat caved, but the underground workings are in good condition.

Several other veins crop out in the immediate vicinity of the Incas vein. One vein lies parallel to it a few tens of feet to the north, and another trending about N. $20^{\circ}$ E. and dipping $70^{\circ} \mathrm{W}$. crops out between the tunnel portal and the blacksmith shop. Several other northward-trending altered zones and quartz veins crop out between the Incas vein and the beach at an altitude of approximately 600 feet.

The Incas vein, in the author's opinion, has not been explored completely, and its possibilities as a mine remain unassessed. The tunnel intersects the vein at a point directly below the northern end of the ore shoot as found on the surface, but exploration was not continued to the south under the area known to contain ore. It would be fairly easy to ascertain if the ore continues to this depth in the area to the south of the point of intersection. For a thousand feet or more to the north of the main prospect, outcrops show that gold-bearing quartz occurs along the altered zone, and, although the maximum thickness of quartz found was about 15 inches, it is possible that small ore bodies of minable grade may occur along this portion of the altered fracture zone.

MONARCH NO. 1

The Monarch No. 1 vein is similar in structure and appearance to the Incas vein. It strikes north to northeast, dips steeply to the west, and crops out over a horizontal distance of nearly 400 feet between the altitudes of 1,875 and 2,000 feet (pl. 4 and fig. 7). The vein is in the same granodiorite body as the Incas vein. The south end of the vein is exposed and is known to pinch out, but the north end is covered by talus, and the full length of the vein is unknown. In general, it appears to be somewhat thicker than the Incas vein.

A tunnel about 225 feet long follows the vein for most of its distance, only leaving it in places where the ground was too loose to permit drifting. A small area was stoped about 55 feet from the entrance to 


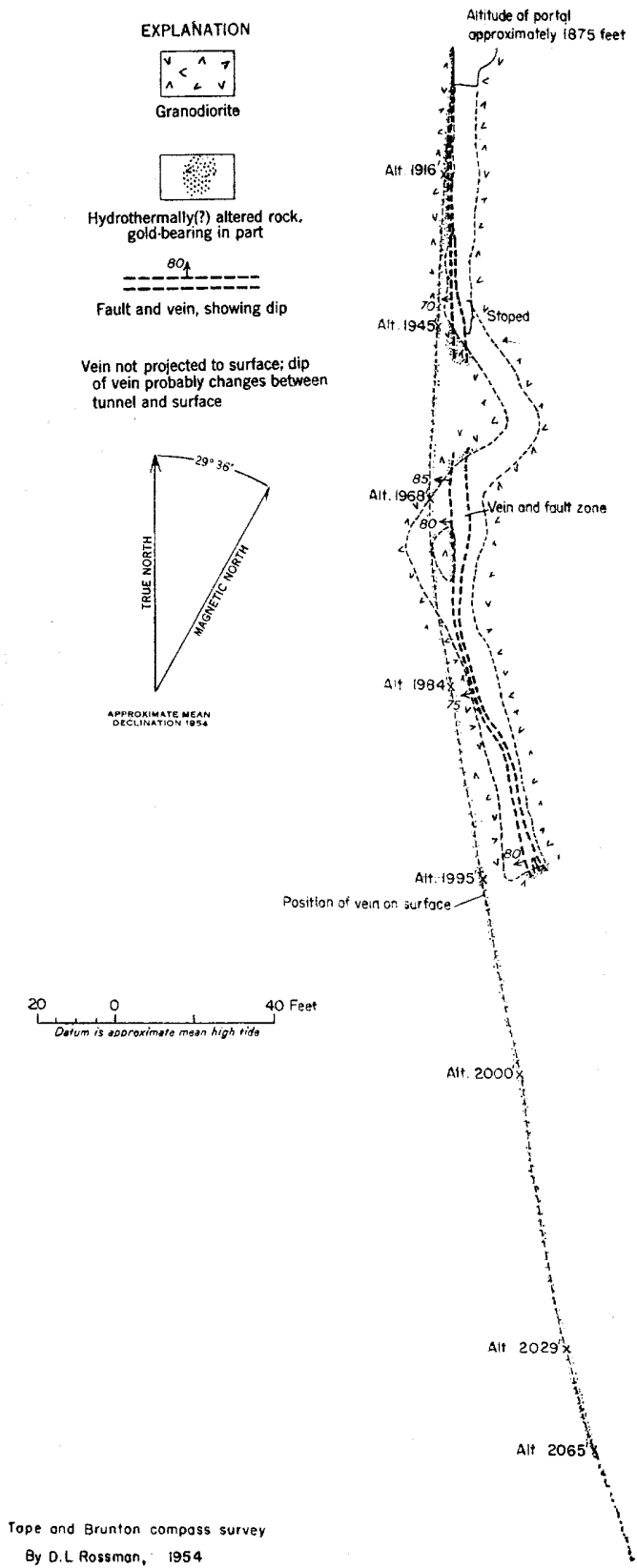

FIGURw 7.-Map of veins and workings at the Monarch No. 1 property. 
the tunnel, and another area about 110 feet in from the portal appears to have been mined upward for a distance of 15 or 20 feet. In the rest of the tunnel to the south of this mined portion, the quartz is too lean to be ore.

While the development work was in progress, an aerial tram extended from the portal of the tunnel eastward to the road at an altitude of about 1,500 feet. The oxidized outcrops along the vein were mined, and the ore was transported by aerial tram to the road, and thence southwestward on the road to a second aerial tram which passed directly over the Incas mine to the beach.

Other veins near the Monarch No. 1 vein also contain some gold. One vein, a few hundred feet to the west of the Monarch No. 1, crops out for a length of about 100 feet and is exposed in several pits near the northern end of the body. The maximum width exposed in 1954 was about 10 inches, but the vein, which strikes north to northeast and has a steep dip, appears to be widening where it passes under cover. Some mining has been done on the partly decomposed weathered material above the vein. A smaller vein about 5 inches wide, which contains abundant pyrite and a small percentage of galena, was found several hundred feet due west of the south end of the Monarch vein. Undoubtedly the stringer is very rich, but it is probably too small to be mined profitably.

Apparently the Monarch No. 1 vein was prospected as much as was deemed advisable, and probably it was felt that the body was either too small or of too low grade to be mined profitably. The vein continues southward beyond the end of the tunnel for at least another 180 feet; but its width is less at the surface than it is in the area directly over the tunnel, and possibly the vein would be no thicker underground than it is on the surface. The author feels that the chance of finding a larger ore body beyond the end of the tunnel, although possible, is not very likely.

\section{MONARCH NO. 2}

The Monarch No. 2 vein is poorly exposed on the surface, but it can be followed over a distance of about 80 feet. Cover in the area beyond its ends is thin, and the vein probably does not extend much beyond the last outcrop. The vein strikes north to northwest and dips steeply to the east. The maximum amount of quartz found on the surface was an 8-inch vein near the southernmost outcrop of the Monarch No. 2. At other places the vein was 2 to 6 inches thick but was not present over the entire 80 feet. The workings on the Monarch No. 2 consist of a tunnel approximately 100 feet long, which starts at an altitude of 1,500 feet at a point about 800 feet northeast of the Monarch No. 1 portal (pl. 4 and fig. 8). The fault along 


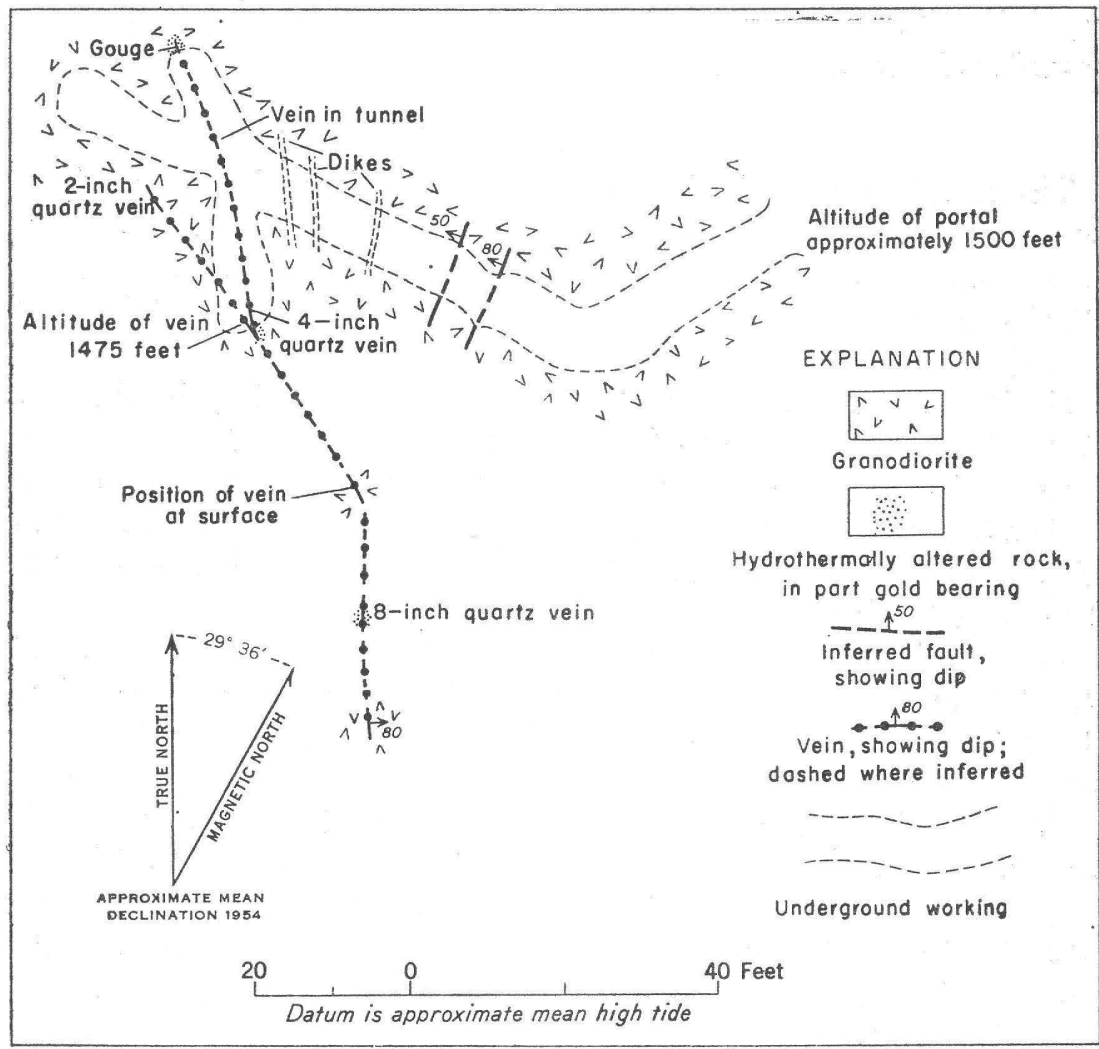

Tape and Brunton compass survey by Darwin L. Rossman, 1954

FIGURE 8.-Map of veins and workings at the Monarch No. 2 property.

which the vein lies was intersected in the tunnel at a distance of about 70 feet from the portal and was followed for a distance of 35 feet. Over this distance are a few lenticular masses of quartz that showed a few small flakes of gold upon panning.

According to Mr. Ibach, another vein apparently of somewhat richer grade cropped out in the area now covered by the dump from the tunnel. This vein, which is poorly exposed on the surface, was reported to contain some galena and free gold and, in Mr. Ibach's opinion, was the better of the two veins. The southern end passes under cover, and outcrops of bedrock a few tens of feet farther south fail to show the continuation of the vein. Also, it apparently does not extend much farther north than the last outcrop. Where exposed, both on the surface and underground, the vein does not offer much encouragement for future work. No ore body has been found, and there is no reason to believe that one lies concealed beneath the talus 
beyond the last outcrop. Hence, any future work on this vein should be undertaken cautiously.

\section{RAINBOW MINE}

The Rainbow mine is the only mine other than the LeRoy from which an appreciable amount of ore has been taken. The Rainbow vein crops out at sea level in the cliff facing the western shore of Glacier Bay about 2,500 feet northeast of the entrance to Reid Inlet (pl.4).

Mining on the Rainbow vein was started by the LeRoy Mining Co. about 1945. The ore taken from the tunnel was loaded directly on a barge and towed to Ptarmigan Creek and thence transported to the mill on the LeRoy Mining Co.'s property. Reportedly, a large amount of high-grade ore was removed from this vein, apparently at a profit to the LeRoy Mining Co.

The vein is in granodiorite along a small fault, which trends about N. $45^{\circ} \mathrm{E}$. and dips $70^{\circ}$ to $80^{\circ} \mathrm{SE}$. The vein is traceable on the surface above the mine for several hundred feet, and the attendant altered zone can be traced to the southwest for a distance of about 2,000 feet. Over most of this distance the quartz vein is missing, but the fault zone is traceable through the presence of the altered rock, which is a bright rust red on weathered outcrops. At the southwest end, at an altitude of 2,000 feet, a quartz vein crops out which is known as the Upper Rainbow vein. The weathered portion of this upper vein has been mined and the gold recovered.

The tunnel that makes up the workings of the Rainbow vein extends along it for a distance of about 200 feet, driving southwest in the cliff face a foot or so above high tide. The vein has been stoped for an unknown distance above this level. For much of this length the vein either has been mined out or is covered by mine timbers so that at only one or two places was it visible. The Rainbow vein is so poorly exposed in the tunnel that worthwhile geologic mapping could not be done underground. The face of the tunnel in 1954 was concealed by loose material that filled the end of the tunnel for some distance.

Not much is known about the reserves in the Rainbow vein, and few recommendations for future work can be made. Apparently the vein continues down below the main working level, but inasmuch as this is very nearly at sea level, future mining operations must be downward. Because the face of the tunnel is concealed, it is not known whether there is ore in the tunnel farther to the south. The presence or absence of ore at the face can be ascertained at practically no expense, however, by simply removing the loose material from the end of the tunnel. Inasmuch as the vein and altered zone can be traced 


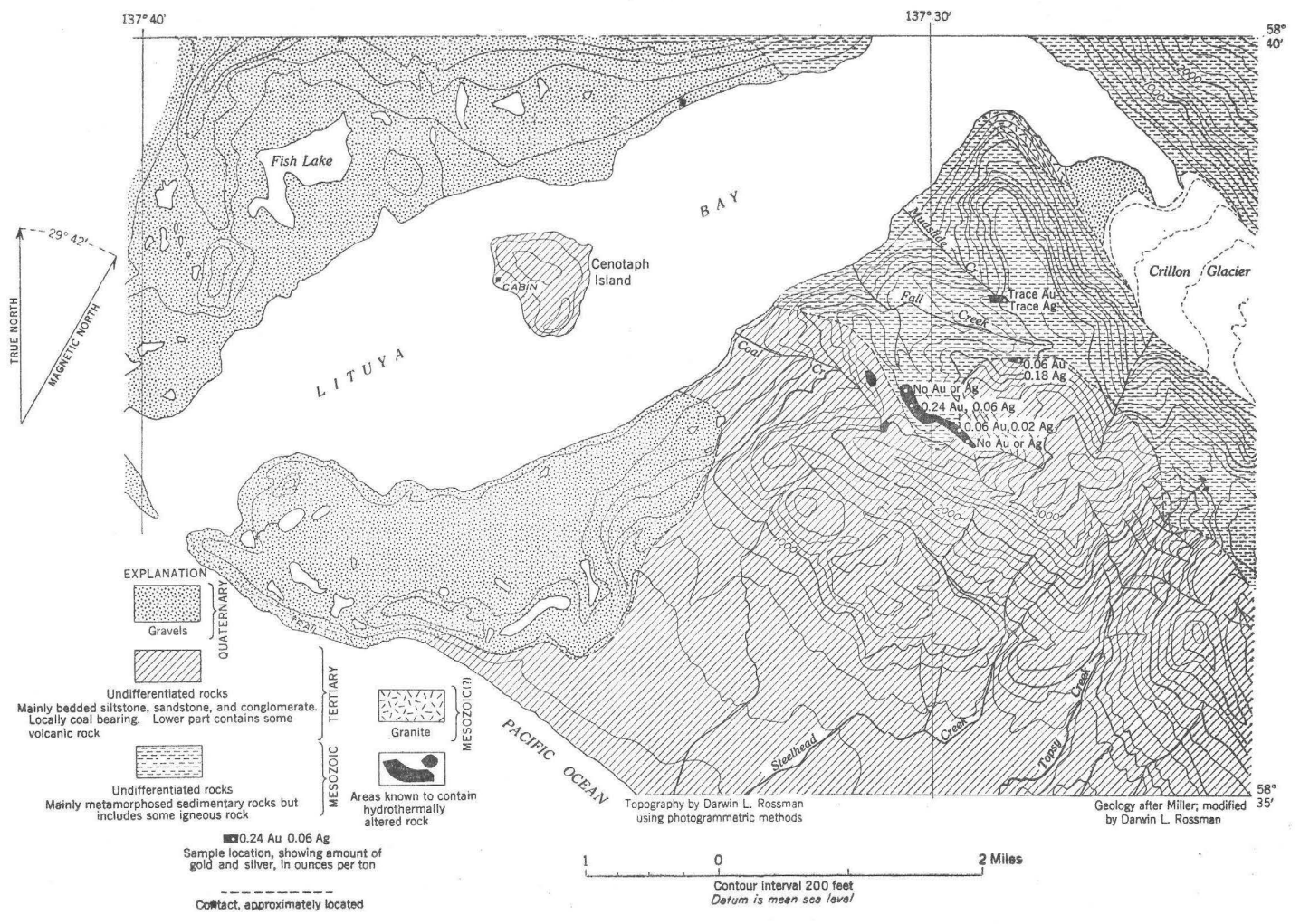

FIGURA 9.-Map showing location of some hydrothermally altered zones near Lituya Bay, Alaska. 
on the surface for a considerable distance to the southwest, exploration in this direction may be justified, but this can be determined best after the face of the tunnel is examined. The ore body at the upper Rainbow claims, which appears to be rather small, crops out over a distance of approximately 75 feet and has an average width of about 10 to 15 inches. The body appears to be too small to merit extensive exploratory work.

\section{SENTINEL VEIN}

A small gold-bearing hydrothermally altered zone, known as the Sentinel vein (pl. 4), crops out on the side of the mountain facing Glacier Bay at an altitude of about 1,900 feet. The Sentinel ore body, now largely mined out, is the only one in the area not associated with quartz that has yielded gold in any significant quantity. The ore occurs along a minor fault and consists of altered granodiorite impregnated by galena and other sulfides. The vein is exposed over a vertical distance of about 50 feet and a horizontal distance of about the same length. The northernmost extension is covered by talus, but the southern end pinches out a few feet above the main workings. The gold-bearing zones is 6 to 10 inches wide. When the deposit was first discovered by Mr. Ibach, a cavity a few feet long existed in the lower part of the ore-bearing zone. The floor of the cavity, Mr. Ibach reports, was covered with a red oxidation product from the vein, which apparently was mainly lead oxide, containing a high concentration of gold. The ore from this prospect was carried to the beach and thence transported to Mr. Ibach's home on Lemesurier Island where it was milled.

\section{HIGHLAND CHIEF CLAIMS}

The Highland Chief claims are near the southern edge of the mapped area just south of Ptarmigan Glacier (pl. 4). The veins crop out between the altitudes of 2,500 and 2,800 feet. The main vein is exposed in a gulch but, because of snow cover, was not visible to the writer during his examination in August 1954. Mr. Ibach reports the vein to be as much as 6 feet wide and to contain a considerable amount of free gold. J. C. Reed visited this property in 1936, and states in his notes that the vein feathers out to the north but disappears under a small glacier to the south. Apparently the vein is somewhat lenticular.

Several other veins crop out on the side of the ridge to the east of the main ore vein at an altitude of about 3,000 feet. Most of these veins are parallel, trending northeast and dipping steeply to the northwest. They appear to be somewhat thicker and more continuous than do those found near the entrance to Reid Inlet. The veins in places are as much as 2 feet thick and can be traced laterally over a 
distance of approximately 700 feet. They pinch out to the north but disappear under cover to the south; therefore, their total length is unknown. All the veins contain some gold; in several, numerous specks of free gold could be seen, even during a rather cursory examination. Other than the veins at the LeRoy mine, those on the Highland Chief claims are the only ones found in the sedimentary rocks. One vein was exposed in the graphitic schist for a few tens of feet.

The parallel veins on the Highland Chief property appear to be the most extensive of any in the area between Reid Inlet and Lamplugh Glacier. They crop out somewhat over a mile from tidewater at an altitude of about 3,000 feet. Undoubtedly these veins would have been mined more actively except for their inaccessibility. For a large part of the year, they are covered by snow, and mining operations would either have to cease or be carried on only with added difficulty and expense.

\section{RAMBLER CLAIMS}

Veins included within the Rambler group of claims crop out on the mountain facing Lamplugh Glacier about 2 miles due south of Mount Parker. The main vein, the Rambler, was discovered by Mr. Ibach sometime before 1940, but it is not known whether it was discovered in 1924 before the Glacier Bay National Monument was closed to prospecting or after it was again opened in 1936.

The area in which these veins occur was not examined in detail. Probably veins exist in this area that are not shown on the geologic map. Most of the veins strike northeast and are nearly vertical. The Rambler vein, however, strikes almost due east. It lies in the granodiorite which is probably part of the same granodiorite mass that crops out immediately west of Reid Inlet. The Rambler vein, the largest vein known in the area, is 3 feet thick in places, but it appears to vary markedly in thickness along the outcrop length. At the western end near Lamplugh Glacier, the vein is covered; to the east it apparently pinches out within a few hundred feet, although its eastern end was not seen by the writer. Where examined, the vein contains considerable pyrite but no galena. However, some float in the creek bed in which the Rambler vein crops out contains abundant galena, sphalerite, and a considerable amount of free gold. This float has a slightly different appearance from the rock in the Rambler vein at the places where it was examined and may well have come from some higher vein or from some part of the Rambler vein not seen.

\section{OTHER VEINS}

Another vein was noted along a fault zone on the west side of Ptarmigan Creek about 3,000 feet southeast of Mount Parker. This 
vein has an exposed length of about 200 feet, but appears to be rather discontinuous and lenticular along its outcrop. No free gold or galena was found in the quartz, but the vein does contain some sphalerite, arsenopyrite, and pyrite. Prospectors who have examined the vein in the past have noticed that it contains a dark-colored mineral which they suspected might be ferberite-an iron tungstate. This mineral has been identified by the writer as iron-rich sphalerite. The fault along which this vein lies can be traced for 4,500 feet to the southwest. The wall rock is altered along its outcrop length and possibly may contain other quartz veins.

A fairly large and continuous vein, not found by the writer, is reported to crop out in the mountain about 1 mile southeast of Mount Parker at an altitude of approximately 3,000 feet.

Two claims were staked on the Whirlaway and Hopalong veins in the area east of Reid Inlet. These veins, which were not visited during 1954, are reported to crop out high on the side of the mountain and apparently are in a crystalline rock with a granitic texture. They contain some free gold, and on both of them some of the weathered surface material has been mined and sluiced and gold recovered.

A few other gold-bearing veins have been prospected in adjacent areas. One crops out of the side of the mountain east of Reid Inlet at an altitude of about 700 feet, in highly shattered rock of sedimentary origin. The vein itself, at least on the surface, is also highly shattered. The shattering has affected all the rock along the side of the mountain for several miles; it does not appear to be part of a major fault zone, and the cause is not known. For most of its length it is covered by slumped debris from the shattered country rock. It is difficult to locate the vein, because reportedly it continues along the side of the mountain for several thousand feet and in places contains some gold. In one locality about due east of the Incas property, the vein is reported to contain some scheelite but apparently in an amount too small to be of any economic importance.

Mr. Ibach found a 1-inch vein of material that he believes to be native arsenic in limestone that crops out on the eastern beach of Reid Inlet about due east of the Incas mine. A small specimen of this material, although not identified, certainly contains considerable arsenic. Both the author and $\mathrm{Mr}$. Ibach searched for the vein during the summer of 1954 but could not find it. Mr. Ibach reported that at the time he found the vein it cropped out in the roof of a small wavecut cavern in the limestone. Since that time, the outcrop has changed considerably and several of the caverns that existed in that area have collapsed. This may be why the vein could not be found. It is also possible that the arsenic is soluble and has dissolved since the time 
of discovery, shortly after the vein was uncovered by the recession of Reid Glacier.

\section{CONCLUSION}

The area between Reid Inlet and Lamplugh Glacier contains many, perhaps several hundred zones along which alteration of the wall rock and gold mineralization have taken place. The rocks in the area are well exposed, and probably most of the important veins have already been discovered. The chief factor that has inhibited continued prospecting and mining in the area seems to be the small size and discontinuous character of the veins. In many of the prospects on which tunnels were driven to reach the ore at depth, the vein or altered zone, when reached, was of considerably lower grade than on the surface.

Probably several factors have been influential in bringing about the belief that the vein decreased in gold content downward from the surface. One is that the ore in the weathered zone has undergone an appreciable enrichment as the quartz and sulfides weathered away and the gold was concentrated on top of the underlying vein. This has given rise to some increase in assay values at the surface. Less quartz is found in some of the tunnels than is found on the surface, owing probably to the tendency of the veins to be lenticular in shape, both horizontally and vertically. There is no sound geologic reason for believing that the lenticular veins might not occur at any place along the altered fault zone below the surface as commonly as they do at the surface. Because the workings are limited in extent, they may, by coincidence, have passed under most of the quartz bodies that they were intended to intersect.

The system of veins at the Highland Chief claims appears to be the strongest and most promising in the mapped area and may some day prove to be the focal point of mining activities. Their inaccessible location with regard both to their situation within the area and the distance from timber and from sources of supplies will be a strong deterrent to their development.

\section{A MINERALIZED AREA NEAR LITUYA BAY}

The following notes are included in this report to call to the attention of prospectors a mineralized area southeast of Lituya Bay. The mineralized area consists mainly of hydrothermally altered rock that was found upon analysis to contain a small amount of gold and silver. The mineralization was first discovered in 1953 when some mapping was done in the area with D. J. Miller. During 1954 a further examination was made to see if a large low-grade ore body might be present. Results of sampling have shown that most of the hydrothermally altered rock is barren but that in a few places it contains a small amount of gold (fig. 9). 
The rocks in the area include a thick sequence of sedimentary and volcanic rocks of Tertiary age that rest unconformably upon a group of older sedimentary and volcanic rocks believed to be of Mesozoic age (fig. 9). This group also includes some crystalline rocks, which are probably igneous in origin. The hydrothermally altered rock, containing gold in places, consists of both the sedimentary rocks of Tertiary age and the older volcanic and sedimentary rocks of Mesozoic age.

In outcrop, the altered rock has a claylike consistency and is commonly reddish yellow. Generally it erodes easily; for this reason, most of its outcrops are found either in stream banks and bottoms or in small gullies and ravines. The material is structurally weak and, where oversteepened by erosion, tends to form small landslides.

The main area of alteration is in the drainage basin of Coal Creek and extends eastward into the headwaters of Fall Creek and Mudslide Creek. Don J. Miller of the U. S. Geological Survey has found similar rock in the upper part of the Topsy Creek drainage (oral communication, 1954). The location of the known outcrops of hydrothermally altered rock are shown on figure 9, but certainly many others are present in the same general area. Possibly hydrothermally altered rock extends beyond the area mentioned.

The results of the assays of samples of the altered rock are shown on figure 9. The highest assay value ( 0.24 ounce per ton) was from an outcrop on the south fork of Fall Creek. It is not known if the gold is free milling so that its presence can be detected by panning. Gold recovered from the gravels of Mudslide Creek probably came from the altered zone at the head of the stream. If the altered rock contains free gold, the best way to prospect might be to pan samples either from the outcrops or from areas where streams have concentrated heavy minerals from the altered zones. Only a small fraction of the total number of altered zones exposed in the area south of Lituya Bay were examined; careful prospecting might possibly disclose some material of economic grade.

\section{REFERENCES CITED}

Buddington, A. F., and Chapin, Theodore, 1929, Geology and mineral deposits of southeastern Alaska : U. S. Geol. Survey Bull. 800.

Miller, D. J., 1953, Preliminary geologic map of Tertiary rocks in the southeastern part of the Lituya district, Alaska: U. S. Geol. Survey, open-file rept. One map and one sheet of correlated columnar sections.

Reed, J. C., 1938, Some mineral deposits of Glacier Bay and vicinity : Econ. Geology, v. 33, no. 1, p. 52-80.

Reed, J. C., and Door, J. V. N., 2d, 1942, Nickel deposits of Bohemia basin and vicinity, Yakobi Island, Alaska : U. S. Geol. Survey Bull. 931-F, p. 105-138. 


\section{INDEX}

\begin{tabular}{|c|c|}
\hline Page & Page \\
\hline (n) & LeRoy Mining $\mathrm{C}_{0} \ldots \ldots$ \\
\hline cknowledgments. & Lituya Bay, geology and mineralization $\ldots . . .57-58$ \\
\hline plite---- & \\
\hline 56 & Metamorphism, granodiorite $\ldots . . . . . .$. \\
\hline Bedded rocks....... & $\begin{array}{l}\text { Metamorphosed sedimentary rocks } \\
\text { Monarch No. } 1\end{array}$ \\
\hline 36 & bearing veins in vicinity \\
\hline Coast Ranges batholith... & $\begin{array}{l}\text { onarch No. } 2 \\
\text { richer-grade vein in vicinity }\end{array}$ \\
\hline Conclusion.. & Mount Fairweather Mining Co..... \\
\hline litic type & ini \\
\hline osition....... & \\
\hline 42 & it Mining Co \\
\hline quar & Olivin \\
\hline ( & sits \\
\hline $44,50,51,5$ & 38 \\
\hline - n & $-41,42$ \\
\hline lity & Produc \\
\hline $39-43$ & Prospecting hints \\
\hline 35,36 & $42,43-44,48,50,51,52,54,57,58$ \\
\hline$t_{1}$ & $8,44,45,52,55$ \\
\hline Id content & $-43,50,55,56$ \\
\hline$-\ldots 44-45$ & 52,57 \\
\hline 56 & $41-42$ \\
\hline $\mathrm{h}$ & \\
\hline res..- & $52-54$ \\
\hline$---55-56$ & $-35-36,44,55$ \\
\hline 44 & $\ldots 35,54$ \\
\hline $41,52,54,55$ & 37 \\
\hline $36,44,54-55,57$ & 45,55 \\
\hline 38,56 & $\begin{array}{r}37,54 \\
57\end{array}$ \\
\hline$-37,46,54,56$ & (n) \\
\hline & Sunrise claim \\
\hline $35,37,46-48$ & \\
\hline . & vein.... \\
\hline $\begin{array}{l}\text { townite } \\
\text { cier }\end{array}$ & 3-1 - \\
\hline 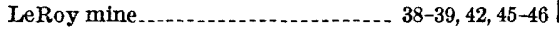 & \\
\hline
\end{tabular}


